\title{
THERMOGRAPHIC DIFFERENTIAL DIAGNOSIS OF ACUTE TONSILLITIS AND EXACERBATION OF CHRONIC TONSILLITIS
}

DOI: 10.36740/WLek202003101

\author{
Mykhaylo A. Andreychyn', Vasyl S. Kopcha', Serhiy I. Klymnyuk', Iuriy M. Andreichyn', Yuliya V. Kopcha², \\ Andriana A. Halamba ${ }^{3}$ \\ II.YA. HORBACHEVSKY TERNOPIL STATE MEDICAL UNIVERSITY, TERNOPIL, UKRAINE \\ 2STATE MUNICIPAL HOSPITAL OF EMERGENCY CARE, TERNOPIL, UKRAINE \\ 'UZHHOROD NATIONAL UNIVERSITY, UZHHOROD, UKRAINE
}

\begin{abstract}
The aim: To elaborate the thermosemiotics of acute and chronic tonsillitis during exacerbation.

Materials and methods: 48 patients with acute tonsillitis and 19 patients with chronic tonsillitis were examined during disease exacerbation. Thermographic examination was carried out by the medical thermometer TI-120. Statistical processing of data was carried out with computer program "Microsoft Excel" and "Statistica for Windows" v. 6.0, StatSoft Inc. (USA).

Results: Symmetry, homogeneity and isotherm are normal thermographic features of the skin. Presence of hyperthermia in carotid triangle, on the palms were revealed in patients with acute tonsillitis. In chronic tonsillitis in the stage of exacerbation, a moderate overall «warming up» of the neck and projections of the submandibular lymph nodes was also observed. The average temperature indices of the knee joints were statistically significantly higher than the corresponding values in healthy people ${ }^{\circ} \mathrm{C}(\mathrm{P}<0.01)$. Conclusion: 0 nly in patients with acute tonsillitis clear strong positive correlation between the temperature of half of the submandibular area and warming in the center of the palm $-r=0.812 \ldots 0.859(P<0.01)$ and in the middle of the tenar on the corresponding side $-r=0.790 \ldots 0.827$ ( $P<0.01)$ was observed. Only in the case of chronic tonsillitis, in the stage of exacerbation, the temperature difference over the knees and the lower part of the femur is always greater than $0.5^{\circ} \mathrm{C}$.
\end{abstract}

KEY WORDS: acute tonsillitis, chronic tonsillitis, thermography, differential diagnosis

Wiad Lek. 2020;73(3):417-422

\section{INTRODUCTION}

Acute tonsillitis is a rapid onset infectious inflammation of tonsils that is the third most common infection after influenza and other acute respiratory infections in etiological structure of infectious morbidity $[1,2]$.

Cases of Streptococcal infection are comprised of more than $50 \%$ of a total number of patients with respiratory infections [3]. It is important that after acute tonsillitis relapsing inflammation of palatine tonsils may be formed. It is favorable for formation of tonsillar diseases (rheumatic fever, myocarditis, glomerulonephritis, pyelonephritis, etc.). These data point out tonsillitis as actual problem of theoretical and practical medicine.

In the last 10 years, the diagnosis of "tonsillitis" became widespread both in Ukraine and in the world.

According to World Health Organization (WHO) data among the world's population about 616 million cases of streptococcal tonsillitis are diagnosed annually [4]. Researches that are carried out in different countries indicate an increase of the cases of streptococcal infections in the human population and the appearance of severe cases of the disease due to the variability of the pathogen [5-8]. Streptococcal infections remain one of the relevant reasons of the population morbidity which allowed WHO to name them an actual medical, social, and economic public health issue $[9,10]$. The relapsing course of streptococcal tonsillitis and it's frequent complications despite of the proper etiotropic therapy allow to hypothesize about existence of unstudied mechanisms in this infectious disease.

The thermographic criteria of acute and chronic tonsillitis in the stage of exacerbation concerned the features of the thermorelief of the anterior half of the neck were described previously. Thus, according to the known method (in a known way), in patients with acute process, a spilled hyperthermia in the projection of the tonsils and submandibular lymph nodes is appeared, but temperature difference with adjacent regions $(\Delta \mathrm{T})$ usually exceeds $0.6^{\circ} \mathrm{C}$, and in chronic cases, limited in area hyperthermia in the upper part of the neck concerning to the type of "collar" with $\Delta \mathrm{T}$ in most patients is $0.3-0.6^{\circ} \mathrm{C}[11,12]$.

However, this method is not sufficiently precise and specific, since the degree of hyperthermia and the area of intensive light directly depend on the level of inflammation in the tonsils, which alleviates the specified thermometric boundaries between acute and chronic tonsillitis.

\section{THE AIM}

To elaborate more clear (or clearer) and specific the thermosemiotics of acute and chronic tonsillitis in the stage of 


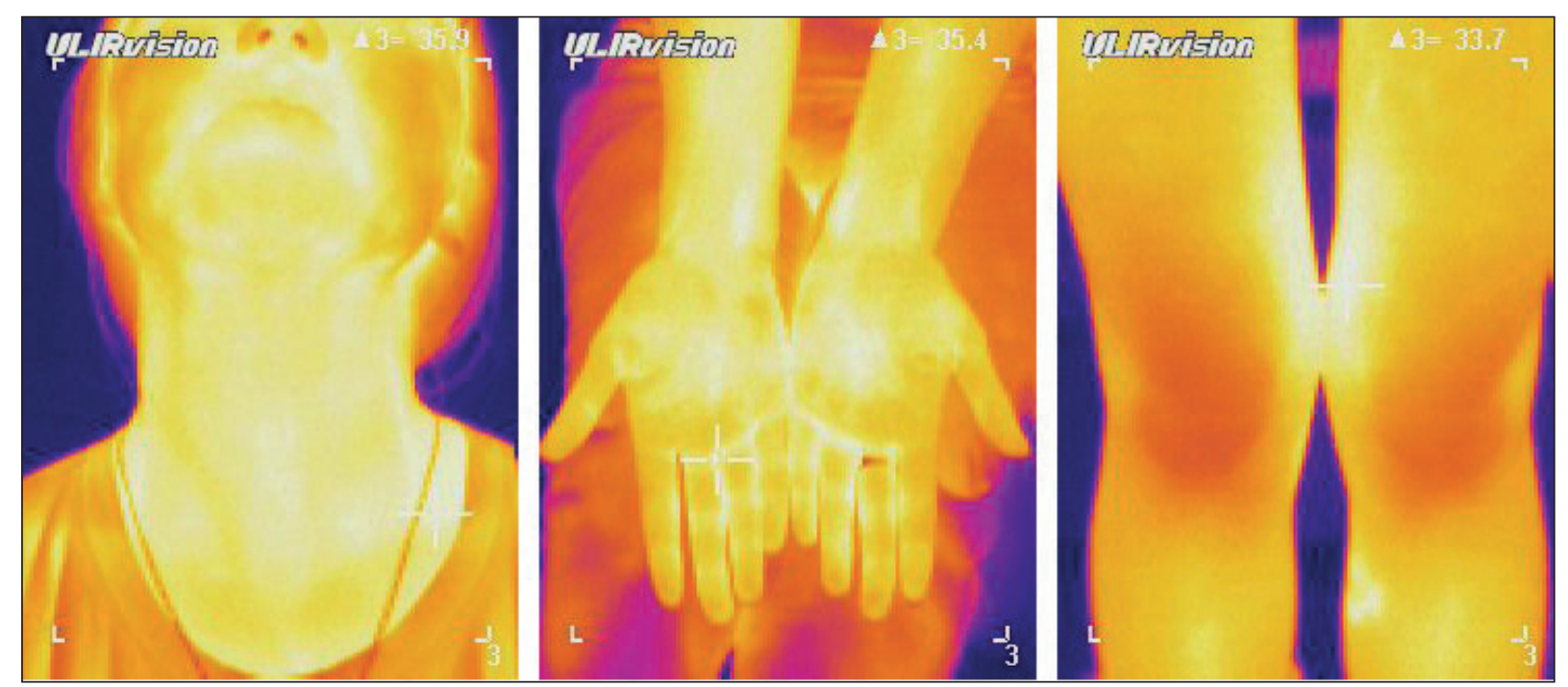

Fig. 1. Patient S.G, 28 years old, with acute tonsillitis. Isothermal temperature distribution of the of the skin of the subnundibullar region, palm, and knees

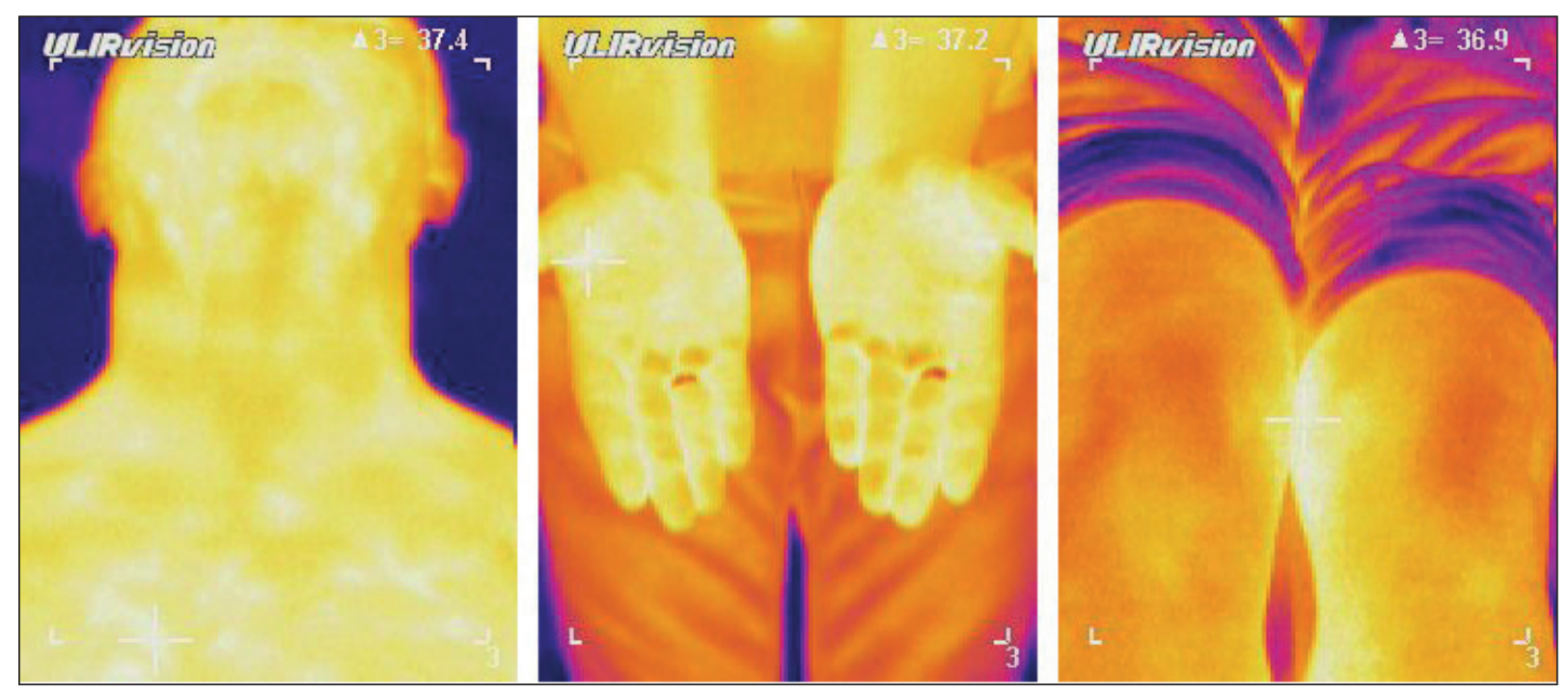

Fig. 2. Patient V.P. 34 years old with acute tonsillitis. Hyperthermal symmetrical temperature distribution of the of the skin of the subnundibullar region, palm, and knees

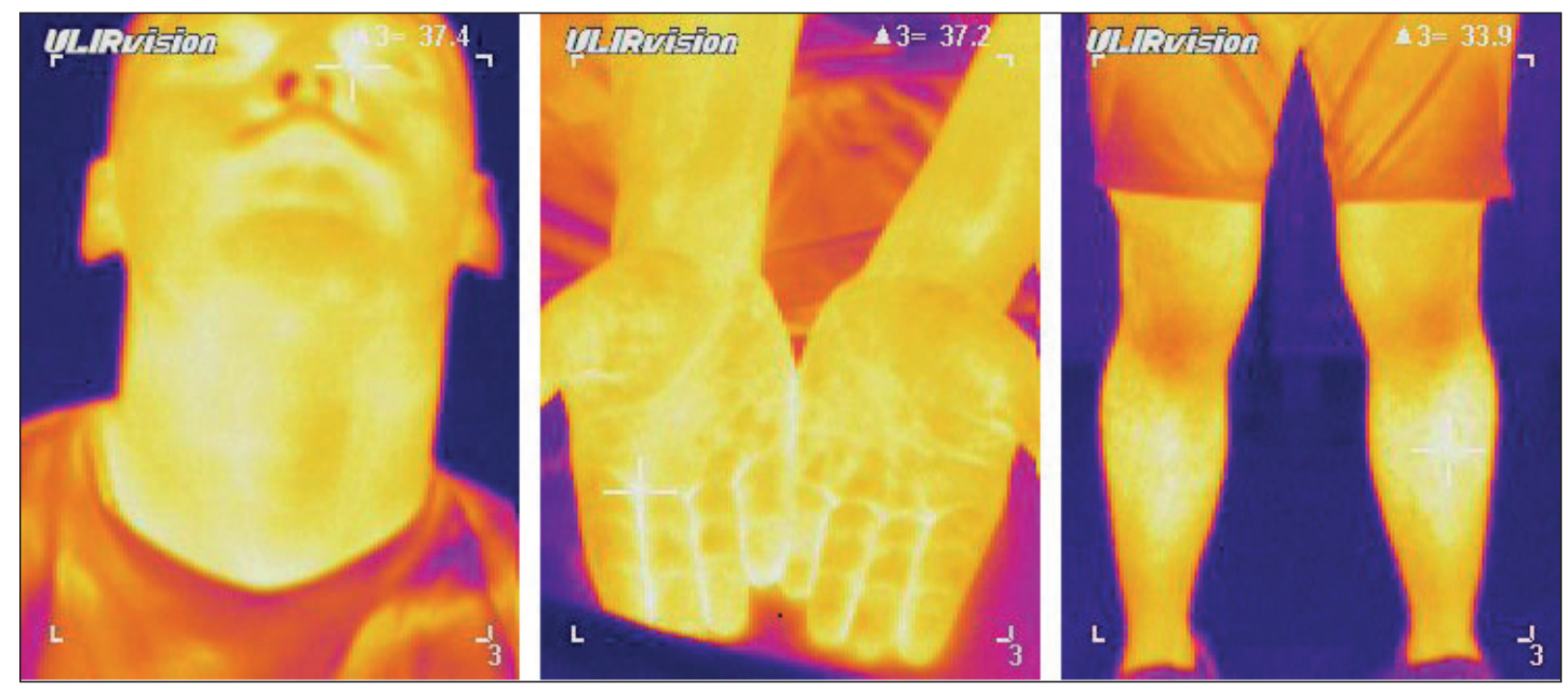

Fig. 3. Patient Ya.N. 24 years old with acute tonsillitis. Hyperthermal asymmetrical temperature distribution of the of the skin of the subnundibullar region, palm, and knees 


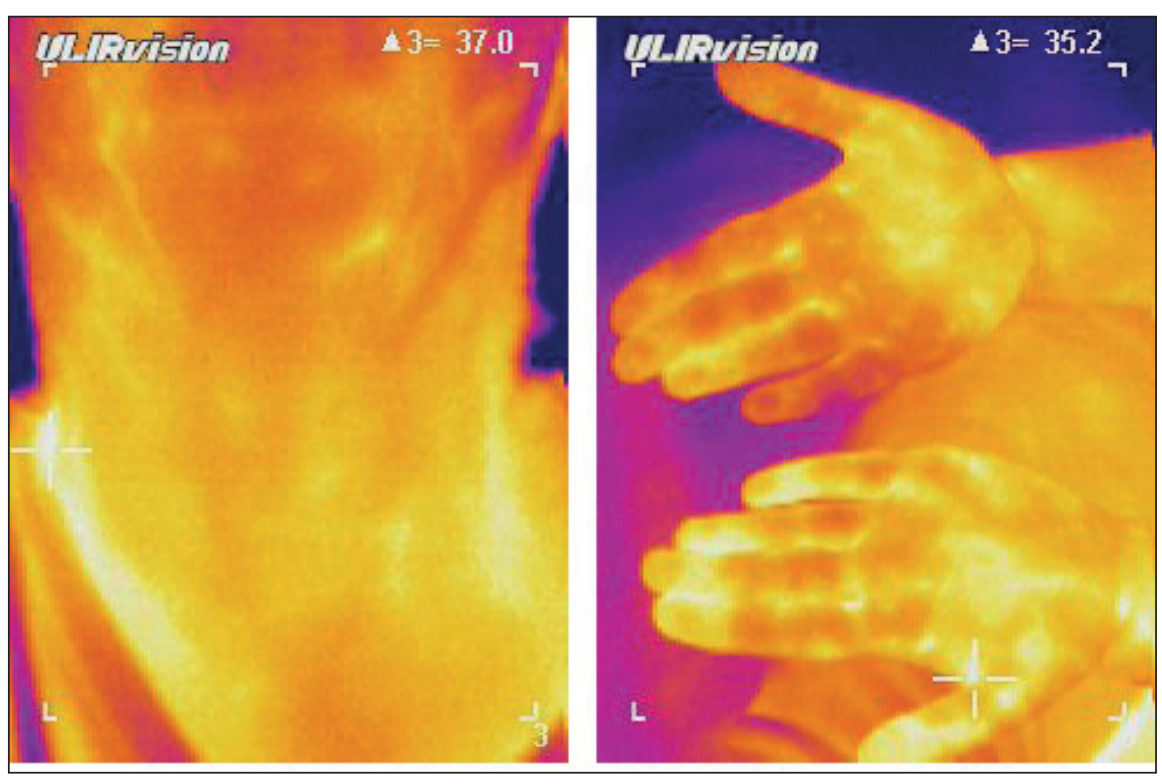

Fig. 4. Thermogram of the anterior part of the neck and palms of patient M.V., 39 years old with chronic tonsillitis in the stage of exacerbation, decompensated form (hyperthermia in the projection of a carotid $-\Delta \mathrm{T}=0.6^{\circ} \mathrm{C}$ and in the middle of palms $\left.-\Delta \mathrm{T}=1.1^{\circ} \mathrm{C}\right)$

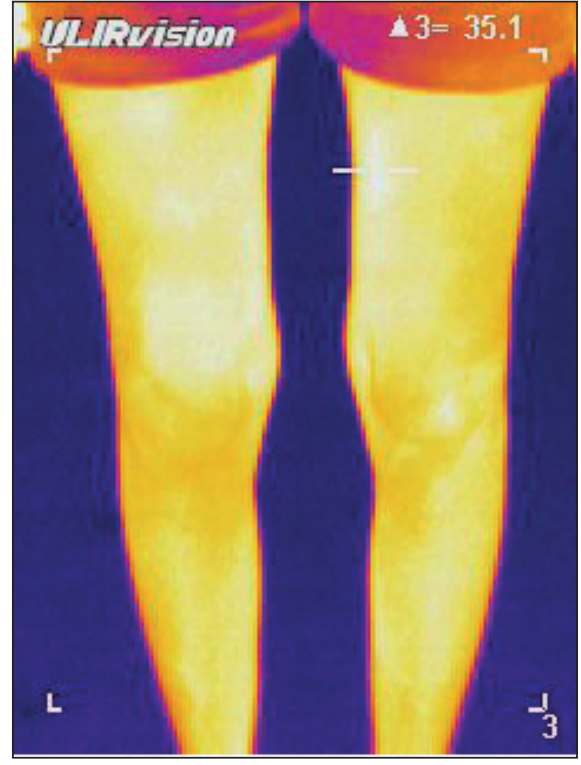

Fig. 5. Termogram of the leg of the same patient (knee hyperthermia $-\Delta \mathrm{T}=1.9^{\circ} \mathrm{C}$ ) exacerbation by determination of the characteristics of infrared radiation in various anatomical sites of such patients.

\section{MATERIALS AND METHODS}

To determine the distinct characteristics of infrared radiation in the submandibular region and on the palms, 48 patients ( 26 men and 22 women) with acute and 19 ( 8 men and 11 women) with chronic tonsillitis in the stage of exacerbation were examined. Their age was between 23 and 58 years with average year (36.8 \pm 13.5$)$. Control group consist of 32 healthy volunteers of the same age with normal body temperature and they had no history of tonsillar pathology. The diagnosis of acute bacterial tonsillitis was made using clinical, laboratory, and instrumental examinations. The survey was conducted at the permission of the Bioethics Commission of I.Ya. Horbachevsky Ternopil State Medical University (Minutes No. 125/18 dated September 26, 2018).

Hyperemia, bloster-like thickening of the edges of the palatine arches, cicatrix comissures between the tonsils and palatine arches, caseous and purulent corks in the tonsillar lacunas, regional lymphadenitis, tonsilogenic intoxication and prolonged subfebrile conditions, as well as anamnestic data about manifestations of decompensation in the form of frequent recurrent acute tonsillitis for a long time. Thus, the signs of chronic tonsillitis in the stage of exacerbation were and reticulum cicatricial adhesions between loose tonsils and palatine arches, cystic-purulent cork, regional lymphadenitis, tonsilogenic intoxication were the main clinical signs of chronic tonsillitis in the stage of exacerbation. To determine the reliability of streptococcal etiology of tonsillitis, the Centor scale of clinical symptoms evaluation was used [13]. Presence of paratonsillitis, parontosillar abscess and other complications, as well as concomitant inflammatory diseases, were the criterion for exclusion of person from the study.
Thermographic inspection was performed using medical thermal imager TI-120. Analysis of thermograms was carried out with the program package "IRSee Software". Thermal images were assessed visually by comparison of the color palette with nearby regions. If there was a thermal asymmetry, thermograms were described by the following algorithm: presence of thermal asymmetry; localization of the zone with increased and reduced intensity of infrared radiation; temperature values and their difference from a symmetrical zone. The thermographic survey of the submandibular region and neck was performed on the patients in sitting position. Apparatus was focused at a distance of about $40-50 \mathrm{~cm}$ from the face in facial projection when the head was tilted back. We paid special attention at a carotid triangle that corresponds to the position of the carotid artery and submandibular lymph nodes, the projection of the larynx and head-nod muscles. Keeping the same distance and projection, thermograph of palms was made. At the same time a temperature of the thenar, finger-tips, hypothenar and the middle of the palm was evaluated.

Statistical processing of data was carried out with computer program "Microsoft Excel" and "Statistica for Windows" v. 6.0, StatSoft Inc. (USA).

\section{RESULTS}

It is known in healthy persons, the temperature distribution of the right and left submandibular regions and both of the palms and knees are symmetrical according to average indices [12]. Mild hypothermia in the projection of the larynx and head-nod muscles, hyperthermal cords along the neck's magistral vessels were the characteristic thermographic features of submandibular regions. The thermal radiation above this zone in absolute figures fluctuated between minimum and maximum values of - 34.2$36.8^{\circ} \mathrm{C}$, with average level $(35.1 \pm 0.7)^{\circ} \mathrm{C}$. In general, following are the features of normal palm and knee teplovision visualization: 
Table I. Distribution of average temperature indices in different anatomical regions in healthy persons and patients with acute tonsillitis in the stage of exacerbation

\begin{tabular}{cccc}
\hline \multirow{2}{*}{ Anatomical region } & \multicolumn{3}{c}{ Average temperature $(\mathbf{M} \pm \mathbf{m}){ }^{\circ} \mathbf{C}$} \\
\cline { 2 - 4 } & healthy persons $(\mathbf{n = 3 2})$ & acute tonsillitis $(\mathbf{n}=\mathbf{4 8})$ & chronic tonsillitis $(\mathbf{n}=\mathbf{1 9})$ \\
\hline Carotid triangle & $35.1 \pm 0.7$ & $37.5 \pm 0.8^{*}$ & $37.1 \pm 0.6^{*}$ \\
\hline Thenar & $34.0 \pm 0.6$ & $36.9 \pm 0.6^{*}$ & $35.3 \pm 0.6$ \\
\hline Middle of the palm & $34.2 \pm 0.6$ & $37.0 \pm 0.7^{*}$ & $35.7 \pm 0.4^{*}$ \\
\hline Knee joints & $32.9 \pm 0.5$ & $33.2 \pm 0.4$ & $35.5 \pm 0.7^{*}$ \\
\hline
\end{tabular}

Note ${ }^{*}$ - a reliable difference compared to a group of healthy individuals $(P<0.05-0.001)$.

Table II. Results of thermal imaging inspection of carotid triangle, palms, and legs in patients with chronic and acute tonsillitis in stage of exacerbation

\begin{tabular}{|c|c|c|c|c|c|c|c|c|c|}
\hline \multirow{3}{*}{ 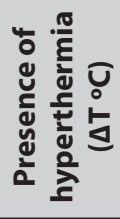 } & \multirow{3}{*}{ Tosillitis } & \multicolumn{8}{|c|}{ Locus } \\
\hline & & \multicolumn{2}{|c|}{ carotid triangle } & \multicolumn{2}{|c|}{ thenar тенар } & \multicolumn{2}{|c|}{ midle of the palm } & \multicolumn{2}{|c|}{ knee joints } \\
\hline & & $\begin{array}{c}\text { abs. } \\
\text { number }\end{array}$ & $M \% \pm m \%$ & $\begin{array}{c}\text { abs. } \\
\text { number }\end{array}$ & $M \% \pm m \%$ & $\begin{array}{c}\text { abs. } \\
\text { number }\end{array}$ & $M \% \pm m \%$ & $\begin{array}{c}\text { abs. } \\
\text { number }\end{array}$ & $M \% \pm m \%$ \\
\hline \multirow{2}{*}{$\begin{array}{c}0-0.5 \\
\text { (Norm } \\
\text { control) }\end{array}$} & Acute $(n=48)$ & 3 & $6.3 \pm 3.5$ & 0 & $0.0 \pm 0.0$ & 0 & $0.0 \pm 0.0$ & 48 & $100.0 \pm 0.0$ \\
\hline & $\begin{array}{l}\text { Chronic in stage of } \\
\text { exacerbation }(n=19)\end{array}$ & 2 & $10.5 \pm 7.0$ & 3 & $15.8 \pm 8.4$ & 2 & $10.5 \pm 7.0$ & 0 & $0.0 \pm 0.0^{*}$ \\
\hline \multirow[b]{2}{*}{$0.6-1.1$} & Acute $(n=48)$ & 16 & $33.3 \pm 6.8$ & 9 & $18.8 \pm 5.6$ & 10 & $20.8 \pm 5.9$ & 0 & $0.0 \pm 0.0$ \\
\hline & $\begin{array}{l}\text { Chronic in stage of } \\
\text { exacerbation }(n=19)\end{array}$ & 11 & $57.9 \pm 11.3$ & 7 & $36.8 \pm 11.1$ & 6 & $31.6 \pm 10.7$ & 3 & $15.8 \pm 8.4$ \\
\hline \multirow[b]{2}{*}{$1.2-1.6$} & Acute $(n=48)$ & 19 & $39.6 \pm 7.1$ & 22 & $45.8 \pm 7.2$ & 19 & $39.6 \pm 7.1$ & 0 & $0.0 \pm 0.0$ \\
\hline & $\begin{array}{l}\text { Chronic in stage of } \\
\text { exacerbation }(n=19)\end{array}$ & 4 & $21.0 \pm 9.3$ & 5 & $26.3 \pm 10.1$ & 8 & $42.1 \pm 11.3$ & 5 & $26.3 \pm 10.1^{*}$ \\
\hline \multirow[b]{2}{*}{$>1.6$} & Acute $(n=48)$ & 10 & $20.8 \pm 5.9$ & 17 & $35.4 \pm 6.9$ & 19 & $39.6 \pm 7.1$ & 0 & $0.0 \pm 0.0$ \\
\hline & $\begin{array}{l}\text { Chronic in stage of } \\
\text { exacerbation }(n=19)\end{array}$ & 2 & $10.5 \pm 7.0$ & 4 & $21.1 \pm 9.4$ & 3 & $15.8 \pm 8.4^{*}$ & 11 & $57.9 \pm 11.3^{*}$ \\
\hline
\end{tabular}

Note. ${ }^{*}$ - a reliable difference at compared with patients with acute tonsillitis in the border of proper range $\Delta T(P<0.05-0.001)$.

symmetry and homogenicity, isotherm with moderate relativehyperthermia of the middle of the palm, fingers of the hand and foot are traced to the fingertips The range of absolute values of palm temperatures was $32.3-34.5{ }^{\circ} \mathrm{C}$, average figures $-(34.2 \pm 0.7){ }^{\circ} \mathrm{C}$. Although in $53 \%$ of healthy individuals, thermal asymmetrycan be registered at $0.2-0.6^{\circ} \mathrm{C}$ with predominance in both the left and right side. Significant differences between male and female were not revealed [14-17]. We found previously that the temperature indices in healthy 20-40 years of age persons were significantly higher by $0.4-0.5^{\circ} \mathrm{C}$ than in eldery persons ( $>40$ years) [12].

Catarrhal inflammation was diagnosed in 3 of examined patients (6.3\%) with acute tonsillitis, follicular - in $11(22.9 \%)$, and 23 persons $(47.9 \%)$ had lacunar inflammation .

According to the character of thermal radiation in patients with acute tonsillitis we distinguished two states - isothermal (19 individuals) and hyperthermic (39 individuals).

In isothermal state temperature distribution in the tissues of the submandibular region and palms, and knees did not differ from the thermogram in control.

Taking into consideration the existence of physiological temperature asymmetry $\pm 0.3^{\circ} \mathrm{Cbetween} \mathrm{the} \mathrm{right} \mathrm{and} \mathrm{left} \mathrm{half}$ of the submandibular region, the palms, and knees such cases of temperature distribution were considered as symmetrical. Figure 1 illustrates these type of heat radiation.
The obtained combination of temperature indices on the histogram and the line of projection of both tonsils proves the absence of differences of thermal radiation in symmetrical regions.

Hyperthermic radiation, is a result of the inflammatory process in the tonsils, which is projected on the submandibular region.

It is important that out of 39 patients with this type of thermal radiation only in 13 persons local hyperthermia was approximately symmetrical (the temperature difference in the pair of parts $-\Delta \mathrm{T}-\operatorname{did}$ not exceed $0.2^{\circ} \mathrm{C}$ ) (Fig. 2), while in the rest - the temperature asymmetry reached even $1.2^{\circ} \mathrm{C}$ (Fig. 3).

It is characteristic that despite of patients' age, in all these cases, the noted difference of temperatures in the carotid triangle, on the palms, primarily in their center and in the middle of the elevation of the thumb-thenar was observed. It is important that the temperature of these areas statistically significantly exceeds the proper value in healthy persons $(\mathrm{P}<0.05-0.001)$. At the same time the temperature of the knee joints did not change (Table 1). It was clear strong positive correlation between the temperature of the half of the submandibular region (the projection of the one of the palatine tonsils and the warming in the middle of the palm $(\mathrm{r}=0.812 \ldots 0.859$ at $\mathrm{P}<0.01)$ and in the middle of the thenar on the corresponding side $-\mathrm{r}=0.790 \ldots 0.827$ at $\mathrm{P}<0.01$. 
In 7 out of 19 patients with chronic tonsillitis in the stage of exacerbation there were compensated, and in the remaining 12 persons -decompensated forms of inflammation.

In exacerbation stage of chronic tonsillitis in thermotopogram of anterior part of the neck showed a moderate warming of the neck, a symptom of a "collar", where, on the background of insignificant hyperthermia brighter focal luminosities in the projection of lymph nodes, mainly submandibular ones were revealed $\left(\Delta \mathrm{T}=0.6^{\circ} \mathrm{C}\right.$, table I. Fig. 4$)$. At the same time, the average temperature indices of the knee joints were statistically significantly higher than the proper values in healthy persons $(35.5 \pm 0.7)$ vs. $(32.9 \pm 0.5)^{\circ} \mathrm{C}(\mathrm{P}<0.01)$. At the same time, other clinical signs of gonitis persecution were excluded.

Table II shows the fact presence fact of hyperthermia in the carotid triangle, on the patients' thenar and in the middle of the palms in absolutive vast of patients with acute tonsillitis, and $\Delta \mathrm{T}$ usually exceeds $0.5^{\circ} \mathrm{C}$, and in every fifth to third - even $1.6^{\circ} \mathrm{C}$. At the same time, no one of these patients was registered warming the knee joints, since this area was practically isothermal with the lower part of the femur $\left(\Delta \mathrm{T}\right.$ does not exceed $\left.0.3^{\circ} \mathrm{C}\right)$. Similarly, on the thermograms of the anterior half of the neck of patients with chronic tonsillitis in the stage of exacerbation hyperthermia of the submandibular area and palms was dominant $\left(\Delta \mathrm{T}\right.$ was predominantly in the range of $\left.0.6-1.6^{\circ} \mathrm{C}\right)$. At the same time, the most significant $\left(>1.6^{\circ} \mathrm{C}\right)$ exceeding of the temperature difference in the middle of the palms in comparing with adjacent areas was found only in $(15.8 \pm 8.4) \%$ of such patients, which was significantly lower than in persons with acute tonsillitis $(39.6 \pm 7.1) \%(\mathrm{P}<0.05)$.

In this case, only in the patients with of chronic tonsillitis in the stage of exacerbation, the in comparison with the lower part of the femur $\left(\Delta \mathrm{T}\right.$ is always greater than $\left.0.5^{\circ} \mathrm{C}\right)$, thermographic inspection of the knees always showed their hyperthermia and in $(57.9 \pm 11.3) \%$ of these patients $\Delta \mathrm{T}$ exceeded $1,6^{\circ} \mathrm{C}$ (Table II, Fig. 5)

Since one of the main pathogenetic links of chronic tonsillitis in the stage of exacerbation is the presence of tonsilogenic intoxication, it can lead to infectious and allergic inflammation of large joints [18].

Let be assume that the degree of hyperthermia of the knee joints reflects the activity of chronic tonsillitis. At the same time, when patient has acute inflammation of palatine tonsils, large joints are not affected.

Conclusion about the degree of compensation of chronic tonsillitis tonsils can be made according to the level of temperature difference over the knees and the lower part of the femur. Thus, in 10 out of 12 patients with decompensated form of tonsillitis, indicated $\Delta \mathrm{T}$ (more than $1.6^{\circ} \mathrm{C}$ ), and in all 7 patients with compensated form - moderate $\left(1.2-1.6^{\circ} \mathrm{C}\right)$. It is important that even without clinical manifestations of joints inflammation, the thermovisual inspection makes it possible to establish initial manifestations of tonsilogenic intoxication in the form of insignificant hyperthermia $\left(\Delta \mathrm{T}=0.6-1.1{ }^{\circ} \mathrm{C}\right)$.

\section{DISCUSSION}

As well in response to penetration of the infectious agent, the inflammatory process develops in the pharyngeal tonsils, which is manifested by local circulatory disturbances, increase of vascular wall permeability, local immunosuppression and, as a consequence, activation of endogenous microflora with e a gradual development of acute inflammation in the tissue of the palatine tonsils [19]. We assume that the marked relationship between the temperature of the submandibular palms, and knees is associated with reflex autonomic changes that lead not only to the dysregulation of the vascular tonus, but also are display remotely from the locus morbi in the Ged zones. As it is known, in the pathogenesis of their formation takes part anatomical and functional (metameric) connection between the skin and inner organs through the segmental apparatus of the spinal cord. In this process, a certain role plays a functional state of the central nervous system.

From the modern point of view Ged zonse may be interpreted as areas with altered sensitivity of the skin and other tissues (muscles, bones) of a certain metamer, a complex vasomotor and motor-trophic reflex, which is believed to be a skin metameric projection of affected internal organ. In these zones tenderness to palpation, changes of trophicity, skin electric conductivity, perspiration, skin temperature and disorder of skin surface sensitivity as hyper- or hypoalgesia were revealed [20].

This assumption is supported by the study of $\mathrm{H}$. Asada et al. (2003), who on the basis of a thermographic examination of 131 patients with chronic tonsillitis in the remission phase found that in 2-4 hours after mechanical massage of the tonsils, the temperature of the palms in some patients increased by $\geq 1^{\circ} \mathrm{C}$. It is interesting that in this group of patients more favorable outcome after tonsillectomy was observed. Therefore researchers suggest to use the thermographic technique and above mentioned provocative palmar test as a marker for prognosis of effectis of tonsillectomy [15]. The same authors point out that in the area between the shoulder girdle and submandibular region a line of the hyperthermia has distinct contours and resembles "the collar", which is a characteristic feature of the toxicoallergic form of chronic tonsillitis.

Thus, the proposed method provides an increase of the informativeness of the differential diagnostic study in patients with acute and chronic tonsillitis in the stage of exacerbation, as well as the possibility of establishing the form of chronic tonsillitis. The peculiarity of thermosemiotics of chronic tonsillitis in the stage of exacerbation established by us is protected by patent [21].

\section{CONCLUSIONS}

1. In patients with acute and chronic tonsillitis the isothermal and hyperthermal (symmetrical and asymmetric) thermal radiation of submandibular areas and palms may be distinguished. Only in patients with acute tonsillitis can be traced a clear strong positive correlation between the temperature of half of the submandibular area (the projection of one of the palatine tonsils) and warming up in the center of the palm $-\mathrm{r}=0.812 \ldots 0.859(\mathrm{P}<0.01)$ and in the middle of the tenar on the corresponding side $-\mathrm{r}=0.790 \ldots 0.827(\mathrm{P}<0.01)$ can be observed.

2. In patients with acute tonsillitis, the regions of knee joints are practically isothermal with the lower part of the femur $\left(\Delta \mathrm{T}\right.$ does not exceed $\left.0.3^{\circ} \mathrm{C}\right)$. 
3. Only in the case of chronic tonsillitis, in the stage of exacerbation, the temperature difference over the knees and the lower part of the femur is always greater than $0.5^{\circ} \mathrm{C}$, and in $(57.9 \pm 11.3) \%$ of these patients $\Delta \mathrm{T}$ exceeds $1.6^{\circ} \mathrm{C}$.

4. The degree of compensation for chronic inflammation of the tonsils can be estimated by the level of temperature difference over the knees and the lower part of the femurs: $\Delta \mathrm{T}$ in the range $1.2-1.6^{\circ} \mathrm{C}$ indicates the compensated form, and $\Delta \mathrm{T}$ which is greater than $1.6^{\circ} \mathrm{C}$ is usually a sign of the decompensated form of chronic tonsillitis.

\section{REFERENCES}

1. Nagoyeva MKh. Patogeneticheskiye aspekty sostoyaniya svobodnoradikalnogo statusa, immuniteta, tsitokinovogo profilya i srednemolekulyarnykh peptidov u bolnykh anginoy [Pathogenetic aspects of the state of free-radical status, immunity, cytokine profile and medium-molecular peptides in patients with angina]. Extended abstract of MDS dissertation (Infectious Diseases), Nalchik, 2010. (in Russian).

2. Mityuryayeva-Korniyko I.A. Tonzillofaringit: sovremennyye predstavleniya 0 zabolevanii, osobennosti antibiotikoterapii [Tonsillopharyngitis: modern concepts of the disease, features of antibiotic therapy]. Ukrayinskyy medychnyy chasopys. 2016;113: 81-85. (in Russian).

3. Molochek Yu.A. Sovremennyye podkhody k diagnostike i lecheniyu tonzillofaringitov (obzor mezhdunarodnykh rukovodstv) [Modern approaches to the diagnosis and treatment of tonsillopharyngitis (a review of international guidelines)]. Aktualna infektolohiya. 2016;12:9-16. (in Russian).

4. Carapetis JR, Steer AC, Mulholland EK, et al. The Current Evidence for the Burden of Group A Streptococcal Diseases. World Health Organization, 2015.

5. Briko NI, Pokrovskiy VI. Infektsii, vyzyvayemyye Streptococcus pyogenes. Streptokokki i streptokokkozy [(ed.) Infections caused by Streptococcus pyogenes. Streptococcus and streptococcosis]. Moskva: GEOTAR-Media; 2009, p. 61-295. (in Russian).

6. KapurV, Topusis S, Majesky MW. A streptococcus pyogenes extracellular cysteine peptease cleares human fibronectin and vitronectin. Microb Patog. 2013;15:323-346.

7. Dajani, AS, Ayoub E, Bierman FZ. Guidelines for the diagnosis of rheumatic fever: jones criteria, updated. JAMA. 2012; 268:2069-2073.

8. Bisno AL. Group A streptococcal infections: The changing scene. Curr Opin Infect Dis. 2005; 8:117-122.

9. Factor SH, Levine OS. Risk factors for Pediatric Invasive Group A Streptococcal Diseases. Emerging Inf. Pis. 2015; 11:1062-1066.

10. Shundi L, Damian M. Streptococcal erythrogenic toxin spe A gene detection by polymerase chain reaction in strains isolated in Albania. Roum Arch Microbiol Immunol. 2007; 56:147-153.

11. Pinter L. Uber die Bewertung des thermographischen Bildes. Klin Monatsbl Augenheilkd. 2010; 196:402-404.

12. Andreychyn M. A, Kopcha Yu.V. Dystantsiyna medychna termohrafiya: suchasni mozhlyvosti ta znachennya pry diahnostytsi hostroho tonzylitu [Remote medical thermography: modern possibilities and meanings in the diagnosis of acute tonsillitis]. Infektsiyni khvoroby. 2016;3:82-88. (in Ukrainian).

13. Meier FA, Centor RM, Graham LJr et al. Clinical and microbiological evidence for endemic pharyngitis among adults due to group $C$ streptococci. Arch. Intern. Med. 1990;150:825-829.
14. Voloshyn HH. Teplova struktura shkiry u zdorovykh osib [The thermal structure of the skin in healthy individuals]. Likarska sprava. 2012;41:20-24. (in Ukrainian).

15. Asada H, Miyagawa S, Tamura M et al. Evaluation of provocation test monitoring palmoplantar temperature with the use of thermography for diagnosis of focal tonsillar infection in palmoplantar pustulosis. Journal of Dermatological Science. 2003;32:105-113.

16. Khizhnyak YeP. Analiz termostruktur biologicheskikh sistem metodom matrichnoy infrakrasnoy termografii [Analysis of the thermal structures of biological systems by themethod of matrixinfrared thermography]. Extended abstract of MDS dissertation (Infectious Diseases).2009; Moscow. (in Russian).

17. Pinter L. Uber die Bewertung des thermographischen Bildes. Klin. Monatsbl Augenheilkd. 2010;196:402-404.

18. Rybak NA. Mikrobiologicheskaya i kliniko-morfologicheskaya diagnostika khronicheskogo tonzillita [Microbiological and clinicalmorphological diagnosis of chronic tonsillitis]. Extended abstract of PhD dissertation (Infectious Diseases). 2017; Minsk. (In Russian).

19. MclsaacWJ, Kellner JD, AufrichtP et al. Empirical validation of guidelines for the management of pharyngitisin children andadults.JAMA. 2004;291:1587-1595.

20. Samosyuk IZ, Samosyuk NI, Yevtushenko SK. Osnovnyye printsipy vybora zon vozdeystviya i ikh obosnovaniye pri ispolzovanii fizicheskikh faktorov v meditsinskoy reabilitatsii [Basic principles of the selection of exposurezones and theirjustification when using physical factors in medical rehabilitation]. Mizhnarodnyynevrolohichnyyzhurnal.2012;54. [E-resource]. (in Ukrainian). Available from: http://www.mif-ua.com/archive/article/34560

21. Andreychyn MA, Kopcha VS, Kopcha YuV, et al. Sposib dyferentsiynoyi diahnostyky hostroho i khronichnoho tonzylitu v stadiyi zahostrennya [Method of differential diagnostics of acute and chronic tonsillitis in the stage of exacerbation]/ Patent 123967. Ukrayina, MPK A61V 5/01 (2006.01). N u2017 10665; Zayavleno 02.11.2017; Opublikovano 12.03.2018, Byul. N 5. (in Ukrainian).

\section{ORCID and contributionship:}

Mykhaylo A. Andreychyn - 0000-0003-0154-730X A

Vasyl S. Kopcha - 0000-0001-9499-3733 ${ }^{D}$

Serhiy I. Klymnyuk -0000-0002-1308-3250 ${ }^{D}$

Iuriy M. Andreichyn - 0000-0002-7789-4466 ${ }^{B, E}$

Yuliya V. Kopcha - 0000-0003-4691-9066 ${ }^{\mathrm{C}}$

Andriana A. Halamba - 0000-0003-0175-9943 ${ }^{F}$

\section{Conflict of interest:}

The Authors declare no conflict of interest.

\section{CORRESPONDING AUTHOR}

\section{Andriana A. Halamba}

PI. Narodna, 1, 88000, Uzhhorod, Ukraine

tel: + 380506715933,

e-mail: andrianagalamba@gmail.com

Received: 17.01 .2020

Accepted: 05.03.2020

A - Work concept and design, B - Data collection and analysis, C - Responsibility for statistical analysis,

D-Writing the article, $\mathbf{E}$-Critical review, $\mathbf{F}$ - Final approval of the article 